\title{
Legal Protection of Safety and Health of Workers
}

\author{
${ }^{1}$ Joupy G. Z. Mambu* \\ Law Studies Program \\ Faculty of Social Science \\ Universitas Negeri Manado \\ Tondano, Indonesia \\ Joupymambu2019@gmail.com
}

\author{
${ }^{2}$ Sam J. R. Saroinsong \\ Law Studies Program \\ Faculty of Social Science \\ Universitas Negeri Manado \\ Tondano, Indonesia \\ samsaroinsong@yahoo.com
}

\begin{abstract}
This research belongs to the category of normative research, which is conducted by examining library materials or secondary data. In ways of effort to protect occupational safety and health, the establishment of regulations is firstly intended to ensure occupational safety and health. Occupational Health aims to assist workers, protecting workers from health problems arising from work and the work environment. The objectives of the research to be achieved are (1) To describe how the legal protection of occupational safety and health according to labor laws (2) To describe the composition and purpose of occupational safety and health efforts according to labor laws. The type of research that will be used to write this law is normative juridical research.
\end{abstract}

Keywords: Legal Protection, Work Safety, Occupational Health

\section{INTRODUCTION}

The Republic of Indonesia, which was proclaimed, on August 17, 1945, was a judicial state. The State of the law in Indonesia already has a precise goal formulation, as stated in the Preamble to the 1945 Constitution of the Republic of Indonesia, called: "... an independent, united, sovereign, just and prosperous Indonesian state." According to the spirit and firmness of the Preamble to the 1945 Constitution of the Republic of Indonesia, it is not just the State of Law Wohlfahrt Staat (prosperity state), but the State of Law of Indonesia is the State of Welfare Law. The Republic of Indonesia, based on the 1945 Constitution, wants not only prosperity in the physical field, but also prosperity in the spiritual field. The people who want life is prosperous, both physically and mentally.

Therefore, the Indonesian Law State is called the Welfare Law State (Verzorgingsstaat)[1]. The Indonesian Prosperous Law State not only protects the entire Indonesian nation and the whole of Indonesia's blood spilled, but the Indonesian State should realize a prosperous and physically prosperous society is materially and spiritually based on the Pancasila and the
1945 Constitution of the Republic of Indonesia, independent, united and sovereign.

By realizing the importance of workers/laborers for the company, it is necessary to make efforts to workers can still exist, and optimal work productivity at work, and one that needs to get positive attention from all parties is the safety and health of workers. Actions in the form of efforts to provide legal protection to occupational safety and health are one of the measures to provide security for workers and work. A sense of peace is one element in creating a sense of happiness. All human behavior, consciously or not, is aimed at achieving happiness. "Humans always try to increase happiness and reduce distress. Good is happiness, and evil is distress. There is a close relationship between good and evil with happiness and distress. "[2]

The International Labor Organization (ILO), one of the United Nations agencies, focuses on the problem of workers throughout the world, one of which also concerns occupational safety and health. They released at least three facts about occupational safety and health.

- Every year, around 24 million people die due to accidents and diseases in the workplace. Within the 24 million people, there are 360 thousand fatal accidents, and an estimated 1.9 million are caused by fatal diseases arisen in the work environment.

- From an economic point of view, if the number of people killed or accidents due to OSH problems, at least $4 \%$ of Global Gross Domestic Product (GPD) can be allocated for the cost of lost work time due to accidents and environmental illness, compensation for workers, cessation of production until medical expenses for workers.

- In Indonesia, in 2015 there were at least 2,375 people who died in workplace accidents. Although the construction industry is the most dangerous, other companies such as manufacturing and food are also dangerous.

The Law on Health states: "Health is a human right and one of the elements of well-being that should be realized according to the ideals of the Indonesian people as intended in the Pancasila and the 1945 Constitution of the Republic of Indonesia." Safety and occupational health for workers is a right means something important for workers. Safety and occupational health are included in individual interest groups, as personal interests. Safety and occupational health are important to get legal protection from the state/government.[3] 
Legal protection is to protect human rights that have been harmed by others and protection is given to the public for they can enjoy all the rights granted by law. The law can be used to realize protections are not merely adaptive and flexible but are also predictive and anticipatory. Law is needed for those who are weak and not strong socially, economically and politically to obtain social justice. The State's obligation to provide legal protection for the safety and health of workers to realize physical and spiritual well-being that is materially and spiritually based on the Pancasila and the 1945 Constitution of the Republic of Indonesia within the framework of the Unitary State of Indonesia which is independent, united and sovereign.

\section{RESEARCH METHODS}

Philosophical legal research seeks to find the ultimate truth of every juridical phenomenon exists and empirical facts occurred. According to Theo Huijber's stated, philosophy is a methodical and systematic intellectual activity, reflecting the essential meaning of the whole.[4] Processing of his mind methodically and systematically. The goal is the truth that makes humans happy. Based on this view Abdulkadir Muhammad concluded[5]: "Important philosophical elements that underlie legal research activities, as follows: a) intellectual activity (logical thinking); b) searching for intrinsic meaning (interpretation); c) all juridical symptoms and empirical facts (objects); d) by way of reflection, methodical, and systematic (method); e) for human happiness.

\section{RESULT AND DISCUSSION}

Legal protection as an illustration of the function of law, such as the concept whereby the law can provide justice, order, certainty, usefulness, and peace. According to Lalu Husni: "To realize work safety protection, the government has made efforts to develop norms in the field of labor. In terms of developing this norm, it includes understanding the formation, application, and supervision of the norm itself. "[6]

Based on the theory of Modern Law Countries or Welfare Law Countries, the formation of labor legislation is conducted with the principle of substantive legality (due process of law substance). The formation of laws and regulations relating to occupational safety and health has fulfilled the values in the principle of substantive legalities (due process of law substance) such as the laws and regulations relating to occupational safety and health contain things contain can realize the existence of legal certainty, equality before the law; there is a legally certain standard in treating workers fairly, logically and not arbitrarily.

Article 86 paragraph (1) of the Manpower Act states:

"Every worker/laborer has the right to obtain protection for: a. occupational Health and Safety;

b. morals and decency; and

c. Treatment by human dignity and values and religious values".

When reviewing the laws and regulations that provide for the protection of occupational safety and health, the protection can be divided into 2 (two) types, namely: 1) preventive legal protection and 2) repressive legal protection.

R. La Porta wrote in the Journal of Financial Economics, the form of legal protection provided by a country has two characteristics, which are prohibited and sanctions. While Henry Arianto, If we observe the labor protection law in Indonesia, then we can see that the nature of labor law protection in Indonesia is Preventive and Repressive.[7]

It is preventive because the law regulates things that do not necessarily occur, but has been set as a preventive measure for something in the future happens to be a concern, then there are guidelines or rules regarding the actions that should be taken. The nature of labor protection is preventive are the rules regarding Occupational Health and Safety (K-3).

The repressive nature of labor protection includes: [6]

1. Social Assistant

The form of this social assistant is the rules regarding the company that is required to provide benefits to employees, such as health benefits as well as compensation for work accidents.

\section{Social Insurance}

This form of social insurance is a corporate benefit to employees. The purpose of this social insurance is to increase the stability of the degree of livelihood in a state of succession, meaning that the employer provides a living for workers without receiving work performance. Social insurance is social security, which means the guarantee or certainty of receiving an allowance from an income if the income is no longer received because of unemployment, illness, an accident or has become an older man until he is unable to work anymore.

The rule of law (Supremacy of law), which in essence emphasizes the existence of normative and empirical recognition of the principle rule of law, such as all-state administration including matters, should be based on the law as the highest guideline. Protection of occupational safety and health in Indonesia can be stated according to the rule of law (supremacy of law), the existence can see this of legal provisions which are the basis of all labor practices in general and legal protection of occupational safety and health in particular.

Protection of occupational safety and health based on these legal provisions is also in line with the principle of legality (due process of law), both the principle of substantive legality (due process of law substance) and the principle of procedural legality (due process of law processes).

From the perspective of the principal substantive legality (due process of law substance), the laws and regulations relating to occupational safety and health have fulfilled the requirements of the principle of 
substantive legality (due process of law substance), such as the legislation relating to occupational safety and health, in essence, contains things realize human treatment in a fair, logical and not arbitrary. Whereas from the perspective of procedural due process of law principle is a formal, logical and proper formal process or procedure, which should be conducted in protecting occupational safety and health; this is evident by the existence of methods or tools and scope which are the focus of occupational safety and health protection.

The steps that need to be taken by the company regarding occupational safety and health are

- Engineering, the management of the company must complete all equipment, machines, and work equipment used by employees with tools or equipment that can prevent or stop accidents and work safety problems.

- Education (Education), this step is the company management provides education and training to workers to instill work habits and safe ways of working in order to achieve maximum results safely. Education and training are given to all employees before they start work, or this program must be a compulsory scheduled activity for the company that is given to employees as part of an orientation event for new employees so that employees' understanding and awareness or concern for occupational safety and health can be cultured since the beginning.

- Implementation (Enforcement), which means company activities to assure that accident control regulations or occupational safety and health programs can be implemented. Ensuring that this step can work, the company can carry out the concept of reward and punishment, which means that the company observes and makes track records of employees both individually or in groups regarding their actions and concern for occupational safety and health programs, in order to prevent accidents and internal work disturbances.

If the purpose of legal protection for occupational safety and health as described is analyzed using the instrument of the Modern Law State Theory or the State of Welfare Law, it can be said that protection of occupational safety and health which is primarily based on statutory regulations is following the principle of the rule of law (Supremacy of law) and the principle of legality (due process of law) and protection of human rights (Human Rights Protection) of the State of Modern Law or the State of Welfare Law.

\section{CONCLUSION}

1. Protection of occupational safety and health is an embodiment of respect and protection by both the State, the law, and the Government, and every person and or worker.

2. Work safety, is the right of workers by the nature of the development of Indonesian people as a whole and the development of the whole Indonesian people.

\section{ACKNOWLEDGMENT}

Thank you for the Dean Faculty of Social Sciences for supporting this research.

\section{REFERENCES}

[1] Azhary, Negara Hukum Indonesia,Analisa Yuridis Normatif tentang Unsur-unsurnya. 1995.

[2] D. D. dan Shidarta, Pokok-Pokok Filsafat Hukum: Apa dan Bagaimana Filsafat hukum Indonesia. Jakarta: Gramedia Pustaka Utama, 2004.

[3] R. Satjipto, Ilmu Hukum, Cetakan Ke. Bandung: Bakti, Citra Adtya, 2000.

[4] T. Huijbers, Filsafat Hukum Dalam Lintasan Sejarah, Cet. 15. Yogyakarta: Kanisius, 2006.

[5] A. Muhammad, , Hukum dan Penelitian Hukum,. Bandung: Citra Aditya Bakti, 2004.

[6] Lalu Husni, Pengantar Hukum Ketenagakerjaan Indonesia, Edisi Revi. Jakarta: Raja Grafindo Persada, 2003

[7] R. La Porta, "Investor Protection and Cororate Governance" J. financ. econ., vol. no. 58, p. hlm. 9., 1999, [Online]. Available: http://repository.uin-suska.ac.id/7119/3/BAB II.pdf. 